\title{
Effects of submergence stress at the vegetative growth stage on hybrid rice growth and grain yield in China
}

\author{
Yutiao Chen ${ }^{1}$, Jiayu Song ${ }^{1}$, Chuan Yan $^{1}$, and Xiaofu Hong ${ }^{1 *}$ \\ ${ }^{1}$ Institute of Crops and Nuclear Technology Utilization, Zhejiang Academy of Agricultural Sciences, Hangzhou 310021, Zhejiang, China. \\ "Corresponding author (hxfzhongfei@163.com).
}

Received: 9 November 2020; Accepted: 15 February 2021; doi:10.4067/S0718-58392021000200191

\begin{abstract}
Submergence stress can greatly limit grain yield of inbred rice (Oryza sativa L.), but the effects of submergence on hybrid rice are unclear. A pot experiment was conducted to clarify the effects of submergence that happens at the vegetative growth stage on two Chinese hybrid rice cultivars. The rice cultivars Zheyou-18, an indica-japonica hybrid, and Yliangyou-689, an indica hybrid, were planted under two treatments, submergence ( $43 \mathrm{~cm}$ depth of tap water for about $2 \mathrm{wk}$ ) and control (no submergence). Results showed that the grain yield of submerged 'Yliangyou-689' was $539.0 \mathrm{~g} \mathrm{~m}^{-2}$ in 2018 and $614.2 \mathrm{~g} \mathrm{~m}^{-2}$ in 2019; submergence significantly reduced grain yield by $49.6 \%$ and $44.2 \%$ of that of the control. The lower level of grain yield was attributed to reduced survival rate, numbers of tillers and spikelets, plant dry weight, and crop growth rate, and excessive elongation of stems due to submergence of plants. The grain yield of submerged 'Zheyou-18' was $466.8 \mathrm{~g} \mathrm{~m}^{-2}$ in 2018 and $376.4 \mathrm{~g} \mathrm{~m}^{-2}$ in 2019 and neither of which were significantly different from that of the control, indicating higher submergence tolerance in 'Zheyou-18' than in 'Yliangyou-689'. Submergence did not affect plant N and K contents, but it reduced plant $\mathrm{N}$ uptake rates by $47.8 \%$ to $88.7 \%$ and it reduced $\mathrm{K}$ uptake rates by $53.9 \%$ to $89.5 \%$ of that of the control in these two hybrid cultivars. Furthermore, nonsignificant differences were observed in all of the parameters related to rice starch viscosity between control and submergence treatment.
\end{abstract}

Key words: Grain yield, growth characters, hybrid rice cultivar, Oryza sativa, rice starch viscosity, submergence tolerance.

\section{INTRODUCTION}

Submergence is considered as one of the most serious abiotic stresses in the world's rice (Oryza sativa L.) production systems (Ella et al., 2011; Gautam et al., 2015). The lowland rice fields in Asiatic countries, totaling more than 22 million hectares, are frequently damaged by submergence (Ismail et al., 2013; Gautam et al., 2014). Because gas diffusion and light radiation are greatly reduced under water, rates of photosynthesis and efficient utilization of carbohydrates are limited and result in the reduction of grain yield in these rice production systems (Bailey-Serres et al., 2012; Kato et al., 2014).

China is one of the largest rice-producing countries in the world, producing more than $30 \%$ of the world's rice outputs (Liu et al., 2019). Approximately 65\% of the Chinese people consume rice as their staple food (Huang et al., 2014). In most riceplanted areas of China, single-season rice is usually seeded in May and transplanted in June. However, the frequent heavy rainfall events occurring from May to June often floods rice fields in the lowland areas when rice plants are at the vegetative growth stage (Hao, 2012). Floods occurring at this stage negatively affects rice growth and grain yield by reducing numbers of tillers, plant leaf area and dry weight above ground, and in the worst case, by causing high mortality (Ella et al., 2011; Kato et al., 2014; Huang et al., 2020). A previous study showed that in China more than four million hectares of rice fields are prone to flooding and the submergence caused yield losses of more than one million tons every year (Chen et al., 2005). 
Identifying the genes that control submergence tolerance in rice is considered as an effective way to promote rice tolerance to flooded conditions. For example, a major quantitative trait locus (QTL) named $S u b l$ was cloned from the rice 'FR13A', which originates from eastern India, has a high submergence tolerance, and can survive for up to 2 wk in complete submergence (Banerjee and Roychoudhury, 2020). Through marker-assisted breeding, the introgression of the Subl gene into high yield cultivars, such as 'Swarna' and 'IR64', has successfully increased these rice cultivars submergence tolerance (Septiningsih et al., 2009; Collard et al., 2013). Compared to traditional cultivars, rice cultivars with higher submergence tolerance usually exhibit some of the following characteristics: higher stem starch concentration before submergence, lower shoot elongation and higher photosynthetic rates during the submergence and stronger capability of recovery after the flood retreats (Kawano et al., 2002; Ella and Ismail, 2006). However, all of the above studies examined inbred rice in Southeast Asia countries, and the studies that investigated submergence tolerance in Chinese rice cultivars, especially hybrid rice cultivars, are limited.

China has more kinds of rice cultivars in production than any other country in the world; the japonica and indica inbreds, indica hybrids and indica-japonica hybrids have all been planted in the country's rice production areas. Heterosis enhances hybrid rice growth and yield, making it superior to inbred rice (Peng, 2016; Wang and Deng, 2018). Consequently, hybrids have been widely planted in China. Several reports showed that hybrid rice accounts for more than $50 \%$ of the rice-planted areas in China and increased China's production of rice to more than 500 million tons in the past four decades (Deng et al., 2013; Li et al., 2013).

Since the 1980s, other countries, such as India, Thailand, the Philippines, Japan and USA began to breed and promote hybrid rice (Chen et al., 2007). Therefore, hybrid rice will play a pivotal role in future food security in China and the majority of the world's countries. In order to meet current and future populations' demands for rice, hybrid rice breeding programs should not only focus on improving grain yield, but also focus on improving abiotic and biotic stress tolerances, resource use efficiencies, and grain qualities of hybrid rice.

For these reasons, we conducted a pot experiment in 2018 and 2019 at Zhejiang Academy of Agricultural Sciences in Hangzhou, China. The objective of this study was to determine the effects of submergence occurring during the vegetative growth stage on grain yield, yield components, starch viscosity characteristics and other growth characteristics of hybrid rice cultivars that are widely grown in China's rice production areas.

\section{MATERIALS AND METHODS}

\section{Experimental design and crop establishment}

The experiment was conducted in a net house in the Institute of Crops and Nuclear Technology Utilization of Zhejiang Academy of Agricultural Sciences ( $\left.30^{\circ} 3^{\prime} \mathrm{N}, 120^{\circ} 2^{\prime} \mathrm{E}\right)$ in Hangzhou, Zhejiang, China, in 2018 and 2019. One indica hybrid rice 'Yliangyou-689' and one indica-japonica hybrid rice 'Zheyou-18' were chosen as experimental materials. They were selected for their high yield potential and because they have been widely planted in the Zhejiang Province. Two treatments were established in which rice plants were either submerged to a height of $43 \mathrm{~cm}$ with tap water for nearly 2 wk (submergence for $12 \mathrm{~d}$ in 2018 and $15 \mathrm{~d}$ in 2019) or not submerged throughout the entire duration of growth (control).

Two concrete tanks $(10.00 \mathrm{~m}$ length $\times 1.25 \mathrm{~m}$ width $\times 0.60 \mathrm{~m}$ depth) were used in this experiment, one for the control and the other for the submergence treatment. In 2018, we filled the control tank with soil and divided it into plots separated by a space of $15 \mathrm{~cm}$ in width. In the submergence tank, we put in plastic trays $(45 \mathrm{~cm}$ length $\times 31 \mathrm{~cm}$ width $\times 15 \mathrm{~cm}$ depth) filled with soil and each tray was considered as one submergence plot. The total area of each control and submergence plot was the same, $0.1395 \mathrm{~m}^{2}$. In 2019, rice plants for both control and submergence treatments were all planted in the plastic trays and then placed into their respective concrete tanks. For the 2018 experiment, thirty 19-d-old seedlings were transplanted to establish six rows of five plants per row in each control and submergence plot. For the 2019 experiment, twenty 15-d-old seedlings were transplanted to establish five rows of four plants per row in each plot. Both the control and submergence plots were established in a completely random design with three replicates for each cultivar for each treatment.

All containers were filled with sandy loam soil ( $\mathrm{pH}=8.03$ ) that consisted of $830 \mathrm{mg} \mathrm{kg}^{-1}$ total $\mathrm{N}, 81 \mathrm{mg} \mathrm{kg}^{-1}$ available K, $42.61 \mathrm{mg} \mathrm{kg}^{-1}$ available $\mathrm{P}$, and $17.2 \mathrm{~g} \mathrm{~kg}^{-1}$ organic $\mathrm{C}$. Chemical fertilizers with $\mathrm{N}, \mathrm{P}$ and $\mathrm{K}$ were applied during rice growth. Nitrogen was applied in the form of urea $(\mathrm{N}: 46 \%)$, $\mathrm{P}$ was applied as superphosphate $\left(\mathrm{P}_{2} \mathrm{O}_{5}: 16.7 \%\right)$ and $\mathrm{K}$ was applied as potassium chloride $\left(\mathrm{K}_{2} \mathrm{O}: 60 \%\right)$. Before transplanting, $2.7 \mathrm{~g}$ urea, $2 \mathrm{~g}$ potassium chloride and $5 \mathrm{~g}$ superphosphate was applied as basal fertilizer. At $14 \mathrm{~d}$ after transplantation, rice plants in the submergence plots were submerged by filling the 
concrete tank with tap water. Ten days after the flood receded, plots were top-dressed with $2.7 \mathrm{~g}$ urea and $2 \mathrm{~g}$ potassium chloride. Pesticides were used to prevent proliferation of insects and diseases.

\section{Percentage of survival}

The number of surviving plants was measured during the recovery period at $21 \mathrm{~d}$ after de-submergence. A surviving plant was defined as one with at least one newly-produced leaf. The percentage of survival was calculated with the following formula:

Percentage of survival $=100 \times($ Number of surviving plants/Total number of plants before submergence $)$

\section{Sampling, physical measurements, and growth rates}

One row of whole-plant samples in each plot was harvested $1 \mathrm{~d}$ before submergence and $1 \mathrm{~d}$ after de-submergence; plants from control and submergence plots were sampled on the same days. The harvested samples were washed with tap water to remove the soil adhering to plant surfaces. Then plant height and number of tillers were recorded. The roots of the plants were cut off and discarded, while the above-ground parts were put into an oven at $75{ }^{\circ} \mathrm{C}$ for $3 \mathrm{~d}$ to dry to a constant weight (dry weight).

At the maturity stage, the three remaining rows of rice plants per plot were harvested in 2018, while the two remaining rows of plants per plot were harvested in 2019. After measuring plant height and number of panicles, each sample was separated into straw and panicles. Panicles were threshed by hand, and the spikelets were separated into filled and unfilled populations (determined by submergence in tap water). All of the filled and unfilled spikelets were counted to record the number of spikelets per panicle. Grain weights and percentage of filled grains were also determined. All plant materials were dried in an oven at $75^{\circ} \mathrm{C}$ to reach a constant dry weight. Measures of the dry weight were used to calculate grain yield and the value was adjusted to $14 \%$ moisture.

The crop growth rate (CGR), shoot elongation rates (SER) during submergence and after de-submergence in submergence and control treatments were calculated from the plant dry weights, the shoot lengths measured $1 \mathrm{~d}$ before submergence, $1 \mathrm{~d}$ after de-submergence and the maturity stage, respectively. The CGR was calculated as the dry weight of rice plant per unit of land area per unit time and the SERs were calculated using the following formulas:

SER during submergence $=100 \times$ (Shoot length $1 \mathrm{~d}$ after de-submergence - Shoot length $1 \mathrm{~d}$ before submergence)

/Shoot length $1 \mathrm{~d}$ before submergence

SER after de-submergence $=100 \times($ Shoot length at maturity - Shoot length $1 \mathrm{~d}$ after de-submergence $)$

/Shoot length $1 \mathrm{~d}$ after de-submergence

\section{Nitrogen and potassium contents}

Plants of the two hybrid rice cultivars that were sampled $1 \mathrm{~d}$ before submergence and $1 \mathrm{~d}$ after de-submergence were ground into a powder by a grinding machine (Zm200, Restch, Germany). Approximately $0.15 \mathrm{~g}$ each powdered sample was taken for digestion by the Kjeldahl method. Then the digestion solution was diluted to measure ammonia and $\mathrm{K}$ concentrations; ammonia concentration was measured by a discrete auto analyzer (Smartchem 200, AMS Alliance, Frépillon, France), and K concentration was measured by a flame photometer (Model 410, Sherwood, UK). Using these measures, $\mathrm{N}$ and $\mathrm{K}$ contents were calculated.

\section{Rice starch viscosity}

The filled-grain samples from each plot were kept for more than 3-mo under ventilated conditions for standby application. The filled grains were mechanically milled (SLJM-2009, Shanghai Shalun, China), then ground into a powder by the grinding machine (Zm200, Restch, Germany) before measuring starch viscosity characteristics of rice. Viscosity characteristics were measured by a rapid visco analyzer (RVA), RVA-TecMaster (Perten Instruments AB, Hägersten, Sweden). We recorded the spectrum of parameters that can be obtained by the RVA, which included: peak viscosity (PV, $\left.\mathrm{mPa} \mathrm{s}^{-1}\right)$, trough viscosity $\left(\mathrm{TV}, \mathrm{mPa} \mathrm{s}^{-1}\right)$, final viscosity $\left(\mathrm{FV}, \mathrm{mPa} \mathrm{s}^{-1}\right)$, breakdown $\left(\mathrm{BD}, \mathrm{mPa} \mathrm{s}{ }^{-1}\right)$, setback $\left(\mathrm{SB}, \mathrm{mPa} \mathrm{s}^{-1}\right)$, peak time (PT, min), and pasting temperature $\left(\mathrm{Pat},{ }^{\circ} \mathrm{C}\right)$.

\section{Statistical analysis}

All data were subjected to statistical testing via ANOVA using Statistic 8 software (Statistix 8, Analytical Software, Tallahassee, Florida, USA), and the means were compared by the least significant difference (LSD) test at a significance level of $\mathrm{P}<0.05$. 


\section{RESULTS}

\section{The percentage of survival after submergence}

The percentages of survival of the two rice cultivars $21 \mathrm{~d}$ after de-submergence are shown in Table 1, and the results indicate that submergence decreased survival rates in both years of study. In 2018, 100\% control plants and 98.3\% submerged plants of both 'Zheyou-18' and 'Yliangyou-689' survived, respectively; 1.7\% difference between control and submergence treatments was nonsignificant in the two cultivars. Of the respective 'Zheyou-18' and 'Yliangyou-689' in $2019,92.3 \%$ and $100 \%$ of individuals in the control treatment and $84.6 \%$ and $69.2 \%$ in the submerged treatment survived. Submergence decreased survival of 7.6\% and 30.8\% of individuals in 'Zheyou-18' and 'Yliangyou-689', respectively, and the difference was significant between control and submergence treatments in 'Yliangyou-689'.

\section{Grain yield and yield components}

Grain yields of 'Zheyou-18' were respectively 661.9 and $466.8 \mathrm{~g} \mathrm{~m}^{-2}$ in the control and submergence treatments in 2018, and yields were respectively 521.5 and $376.4 \mathrm{~g} \mathrm{~m}^{-2}$ in the control and submergence treatments in 2019 (Table 2). However, the differences were nonsignificant between control and submergence treatments in both years. Of 'Yliangyou-689', grain yields were respectively 1073.0 and $540.5 \mathrm{~g} \mathrm{~m}^{-2}$ in the control and submergence treatments in 2018, and yields were respectively 1069.9 and $539.0 \mathrm{~g} \mathrm{~m}^{-2}$ in the control and submergence treatments in 2019; these differences were significant. The submergence treatment significantly reduced grain yield by $49.6 \%$ and $44.2 \%$ in 'Yliangyou- 689 ' and insignificantly reduced grain yield by $29.5 \%$ and $27.8 \%$ in 'Zheyou-18' from that of their respective controls.

Lower spikelet number was observed in the submergence treatment than in the control of both hybrid cultivars, and the difference was significant except of 'Zheyou-18' in 2019. Panicle number of the control treatment was lower than that of the submergence treatment in both cultivars; however, the differences were only significant in 'Yliangyou-689'. The number of spikelets per panicle, percentage of filled grains, and grain weight exhibited inconsistent trends in the control and submergence treatments in the $2 \mathrm{yr}$.

\section{Rice growth characters}

Nonsignificant difference was observed in mean tiller number between the control and submergence treatments before submergence, except of 'Yliangyou-689' in 2018 where the control treatment showed a significantly higher tiller number than that of the submergence treatment (Figure 1). The submergence treatment reduced the tiller number greatly, and when the flood receded, significantly lower tiller numbers were observed from the submergence treatment

Table 1. Percentages of survival of two rice cultivars subjected to submergence or not (control).

\begin{tabular}{|c|c|c|c|}
\hline Year & Cultivar & Treatment & Survival \\
\hline & & & $\%$ \\
\hline \multirow[t]{4}{*}{2018} & Yliangyou-689 & Control & $100.0 \mathrm{a}$ \\
\hline & & Submergence & $98.3 \mathrm{a}$ \\
\hline & Zheyou-18 & Control & $100.0 \mathrm{a}$ \\
\hline & & Submergence & $98.3 \mathrm{a}$ \\
\hline \multirow[t]{10}{*}{2019} & Yliangyou-689 & Control & $100.0 \mathrm{a}$ \\
\hline & & Submergence & $69.2 b$ \\
\hline & Zheyou-18 & Control & $92.3 \mathrm{a}$ \\
\hline & & Submergence & $84.6 \mathrm{a}$ \\
\hline & & ANOVA results & \\
\hline & & Year $(\mathrm{Y})$ & NS \\
\hline & & Treatment $(\mathrm{T})$ & $*$ \\
\hline & & Cultivar (C) & NS \\
\hline & & $\mathrm{Y} \times \mathrm{T}$ & $*$ \\
\hline & & $\mathrm{C} \times \mathrm{T}$ & ns \\
\hline
\end{tabular}

Within columns for each treatment, means followed by different letters are significantly different according to LSD $(\mathrm{P}<0.05)$.

$*, * *$ Significant at the 0.05 and 0.01 probability levels, respectively. NS: Nonsignificant. 
Table 2. Grain yields and yield components of two rice cultivars subjected to submergence or not (control).

\begin{tabular}{|c|c|c|c|c|c|c|c|c|}
\hline Year & Cultivars & Treatments & Grain yield & $\begin{array}{c}\text { Spikelets } \\
\text { number }\end{array}$ & $\begin{array}{l}\text { Panicle } \\
\text { number }\end{array}$ & $\begin{array}{c}\text { Spikelets } \\
\text { per panicle }\end{array}$ & Grain filling & Grain weight \\
\hline & & & $\mathrm{g} \mathrm{m}^{-2}$ & $\mathrm{Nr} \mathrm{m}^{-2}$ & $\mathrm{Nr} \mathrm{m}^{-2}$ & & $\%$ & $\mathrm{mg}$ \\
\hline \multirow[t]{4}{*}{2018} & Yliangyou-689 & Control & $1069.9 \mathrm{a}$ & $52708 \mathrm{a}$ & $296.1 \mathrm{a}$ & $182.2 \mathrm{a}$ & $77.9 \mathrm{a}$ & $22.4 \mathrm{a}$ \\
\hline & & Submergence & $539.0 \mathrm{~b}$ & $34145 b$ & $133.8 \mathrm{~b}$ & $256.7 \mathrm{a}$ & $66.7 \mathrm{~b}$ & $20.4 b$ \\
\hline & Zheyou-18 & Control & $661.9 \mathrm{a}$ & $42211 a$ & $191.0 \mathrm{a}$ & $220.2 \mathrm{a}$ & $67.1 \mathrm{~b}$ & $20.2 \mathrm{a}$ \\
\hline & & Submergence & $466.8 \mathrm{a}$ & $20998 b$ & $148.0 \mathrm{a}$ & $144.3 b$ & $88.5 \mathrm{a}$ & $21.7 \mathrm{a}$ \\
\hline \multirow[t]{9}{*}{2019} & Yliangyou-689 & Control & $1101.8 \mathrm{a}$ & $66571 \mathrm{a}$ & $390.4 \mathrm{a}$ & $169.7 \mathrm{a}$ & $70.9 a$ & $20.2 \mathrm{a}$ \\
\hline & & Submergence & $614.2 b$ & $34886 b$ & $261.9 \mathrm{~b}$ & $187.4 \mathrm{a}$ & $72.7 \mathrm{a}$ & $20.9 a$ \\
\hline & Zheyou-18 & Control & $521.5 \mathrm{a}$ & $55205 \mathrm{a}$ & $223.9 \mathrm{a}$ & $249.8 \mathrm{a}$ & $40.8 \mathrm{a}$ & $20.0 \mathrm{a}$ \\
\hline & & $\begin{array}{l}\text { Submergence } \\
\text { ANOVA results }\end{array}$ & $376.4 \mathrm{a}$ & $44524 a$ & $161.9 \mathrm{a}$ & $275.4 \mathrm{a}$ & $37.5 \mathrm{a}$ & $19.3 \mathrm{a}$ \\
\hline & & Year (Y) & NS & $* *$ & $*$ & NS & $* *$ & NS \\
\hline & & Treatment $(\mathrm{T})$ & $* *$ & $* *$ & $* *$ & NS & NS & NS \\
\hline & & Cultivar (C) & $* *$ & NS & $* *$ & NS & NS & NS \\
\hline & & $\mathrm{Y} \times \mathrm{T}$ & NS & NS & NS & NS & NS & NS \\
\hline & & $\mathrm{C} \times \mathrm{T}$ & $* *$ & NS & NS & NS & NS & NS \\
\hline
\end{tabular}

Within columns for each treatment, means followed by different letters are significantly different according to LSD (P $<0.05$ ).

$*$, **Significant at the 0.05 and 0.01 probability levels, respectively. NS: Nonsignificant.

than from the control in both years and both rice cultivars, with the exception of 'Zheyou-18' in 2018. Compared to their respective controls, the submergence treatment significantly reduced dry weights of plants sampled at $1 \mathrm{~d}$ after de-submergence of the two cultivars in both years (Table 3). Moreover, we also observed lower CGR in submerged rice during submergence than that in the control treatment, and the differences were significant in most cases.

Both 'Zheyou-18' and 'Yliangyou-689' control plants grew taller than their respective submerged plants prior to the submergence treatment. The difference was significant in 2018, while nonsignificant difference was observed between the control and submergence treatments in 2019 (Figure 2). When flooding receded, plants in the submergence treatment were on average taller than plants in the control, except the 'Zheyou-18' plants grown in 2018, and the differences were significant in 2019. At the maturity stage, mean height of control plants was significantly higher than that of submergence individuals, with the exception of the difference between 'Zheyou-18' plants in 2019. The submergence treatment increased SER significantly during submergence in both years, with the exception of 'Zheyou-18' in 2019 where the difference between control and submergence plants was nonsignificant (Figure 3). However, SER from de-submergence to maturity was significantly higher in the control treatment than in the submergence treatment in both hybrid cultivars in both years.

\section{Contents and uptake of $\mathbf{N}$ and $\mathrm{K}$}

The contents of $\mathrm{N}$ and $\mathrm{K}$ were measured from the rice sampled $1 \mathrm{~d}$ before submergence and $1 \mathrm{~d}$ after de-submergence (Table 4). We found that $\mathrm{N}$ contents ranged from 21.6 to $37.9 \mathrm{mg} \mathrm{g}^{-1}$ and from 25.3 to $38.9 \mathrm{mg} \mathrm{g}^{-1}$ in 'Yliangyou-689' and 'Zheyou-18', respectively. And K contents ranged from 35.6 to $43.4 \mathrm{mg} \mathrm{g}^{-1}$ and from 36.5 to $44.4 \mathrm{mg} \mathrm{g}^{-1}$ in 'Yliangyou-689' and 'Zheyou-18', respectively. Nonsignificant differences were observed between the control and submergence treatment in $\mathrm{N}$ and $\mathrm{K}$ contents of both hybrid rice in the two experimental years.

The rate of $\mathrm{N}$ uptake ranged from 0.68 to $13.98 \mathrm{~g} \mathrm{~m}^{-2}$ and from 0.71 to $19.80 \mathrm{~g} \mathrm{~m}^{-2}$ in 'Yliangyou-689' and 'Zheyou-18', respectively (Table 4). Potassium uptake rate ranged from 0.67 to $17.99 \mathrm{~g} \mathrm{~m}^{-2}$ and from 0.77 to $23.28 \mathrm{~g} \mathrm{~m}^{-2}$ in 'Yliangyou-689' and 'Zheyou-18', respectively. The submergence treatment reduced plant $\mathrm{N}$ uptake rates by $47.8 \%$ to $88.7 \%$ and it reduced plant $\mathrm{K}$ uptake rates by $53.9 \%$ to $89.5 \%$ of that of the control in these two hybrid cultivars, and the difference was significant except $\mathrm{N}$ uptake of 'Zheyou-18' in 2019.

\section{Rice starch viscosity characteristics}

We determined the properties of starch viscosity from the two hybrid rice cultivars grown under the control and submergence treatments (Table 5). There were nonsignificant differences in the two hybrid rice cultivars between control and submergence treatment in all of the data outputs of the RVA. The only exception was the peak viscosity (PV) of 'Yliangyou-689' in 2018, when the submerged plants showed a significantly higher PV value than that of the nonsubmerged plants of the control. 
Figure 1. Number of tillers from two rice cultivars counted $1 \mathrm{~d}$ before submergence (BS), $1 \mathrm{~d}$ after de-submergence (AS) and maturity stage (MS). Control plants were not submerged and were measured at the same time as the submerged plants.
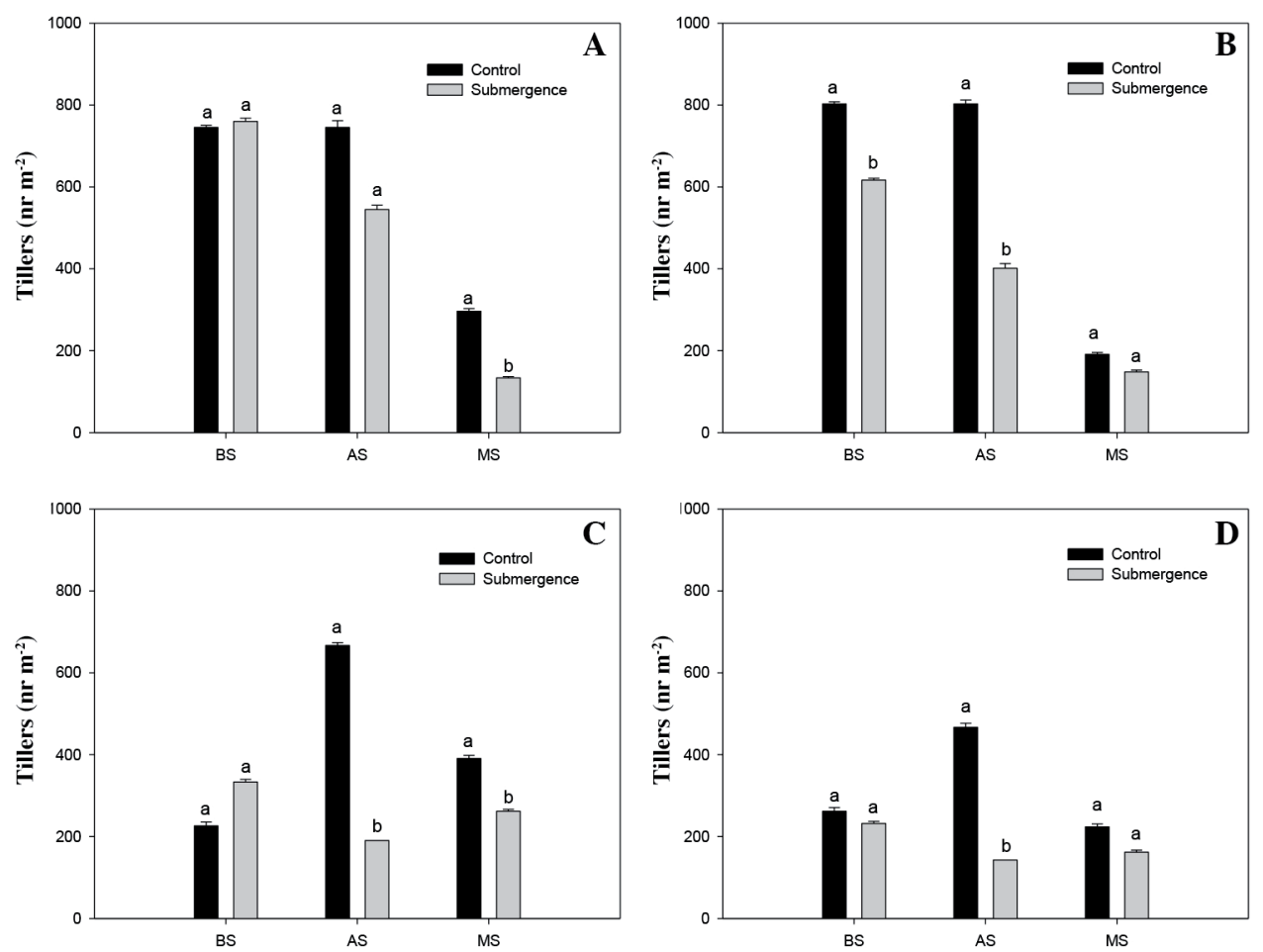

Vertical bars represent the SE of the means $(n=3)$.

Within each sampling period in each year, bars marked by different letters are significantly different according to LSD $(\mathrm{P}<0.05)$. A: 'Yliangyou-689' in 2018; B: 'Zheyou-18' in 2018; C: 'Yliangyou-689' in 2019; D: 'Zheyou-18' in 2019.

Table 3. Dry weight and crop growth rate of two rice cultivars subjected to no submergence (control) or submergence treatments.

\begin{tabular}{|c|c|c|c|c|c|}
\hline Year & Cultivars & Treatment & BS & AS & CGR $_{\text {BS-AS }}$ \\
\hline & & & $\longrightarrow$ & - & $\mathrm{g} \mathrm{m}^{-2} \mathrm{~d}^{-1}$ \\
\hline \multirow[t]{4}{*}{2018} & Yliangyou-689 & Control & $350.7 \mathrm{a}$ & $424.6 \mathrm{a}$ & $6.2 \mathrm{a}$ \\
\hline & & Submergence & $153.6 \mathrm{~b}$ & $153.6 \mathrm{~b}$ & $0.0 \mathrm{a}$ \\
\hline & Zheyou-18 & Control & $314.5 \mathrm{a}$ & $526.1 \mathrm{a}$ & $17.6 \mathrm{a}$ \\
\hline & & Submergence & $66.7 \mathrm{~b}$ & $58.0 \mathrm{~b}$ & $-0.7 b$ \\
\hline \multirow[t]{10}{*}{2019} & Yliangyou-689 & Control & $17.9 \mathrm{~b}$ & $173.6 \mathrm{a}$ & $10.2 \mathrm{a}$ \\
\hline & & Submergence & $28.5 \mathrm{a}$ & $86.8 \mathrm{~b}$ & $3.9 \mathrm{~b}$ \\
\hline & Zheyou-18 & Control & $19.0 \mathrm{a}$ & $127.1 \mathrm{a}$ & $7.2 \mathrm{a}$ \\
\hline & & Submergence & $21.4 \mathrm{a}$ & $52.5 \mathrm{~b}$ & $2.1 \mathrm{~b}$ \\
\hline & & ANOVA results & & & \\
\hline & & Year (Y) & $* *$ & $* *$ & NS \\
\hline & & Treatment $(\mathrm{T})$ & $* *$ & $* *$ & $* *$ \\
\hline & & Cultivar (C) & NS & NS & NS \\
\hline & & $\mathrm{Y} \times \mathrm{T}$ & $* *$ & $* *$ & NS \\
\hline & & $\mathrm{C} \times \mathrm{T}$ & NS & NS & NS \\
\hline
\end{tabular}

$\overline{\text { Within columns for each treatment, means followed by different letters are significantly different }}$ according to $\operatorname{LSD}(\mathrm{P}<0.05)$.

BS: $1 \mathrm{~d}$ before submergence; AS: $1 \mathrm{~d}$ after de-submergence; MS: maturity stage; CGR: crop growth rate.

$*$,**Significant at the 0.05 and 0.01 probability levels, respectively. NS: Nonsignificant. 
Figure 2. Plant heights of two rice cultivars sampled at three time points: $1 \mathrm{~d}$ before submergence (BS), $1 \mathrm{~d}$ after desubmergence (AS), and maturity stage (MS). Control plants were not submerged and were measured at the same time as the submerged plants.
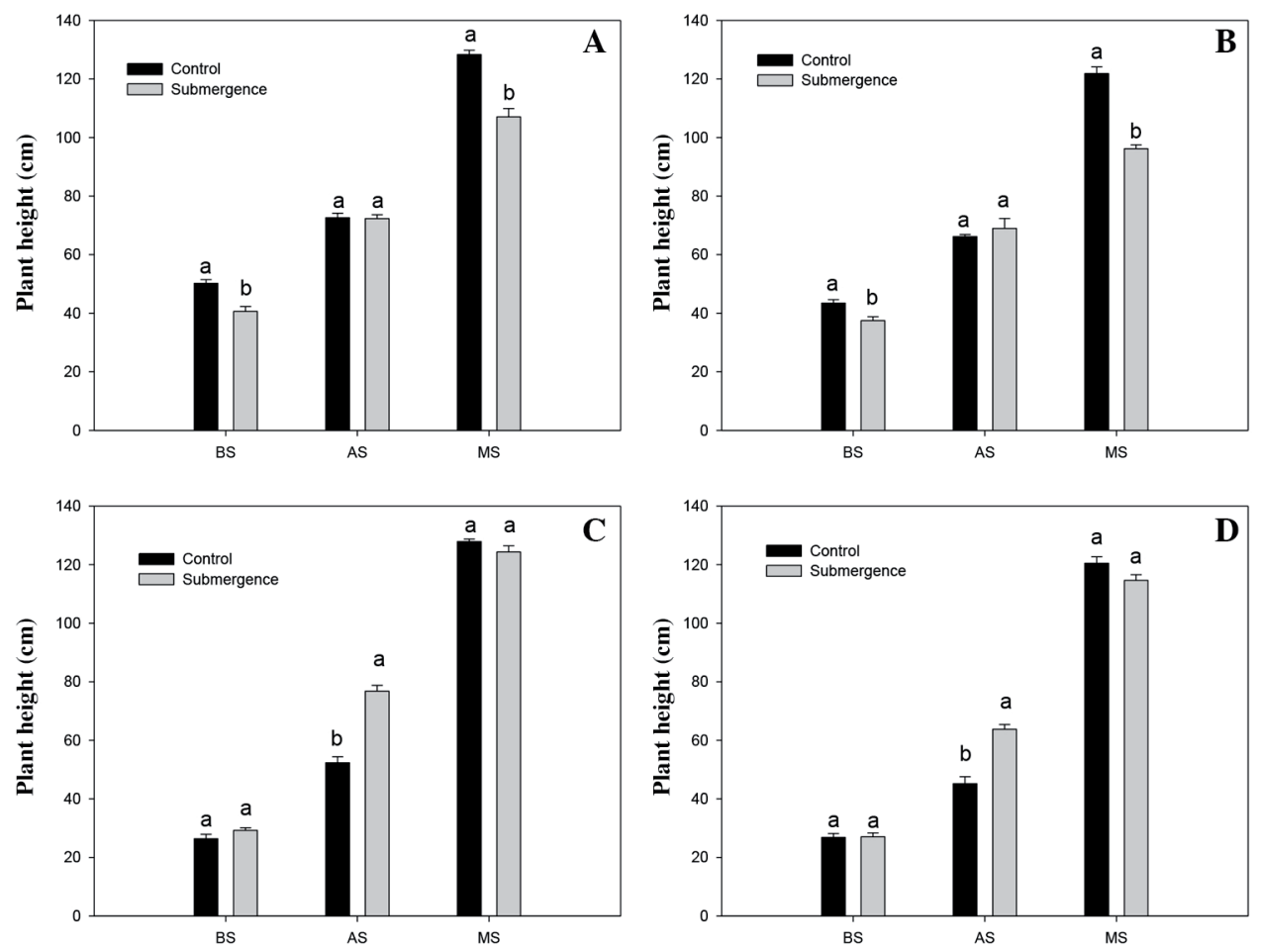

Vertical bars represent the SE of the means $(n=3)$.

Within each sampling period in each year, bars marked by different letters indicate significantly different means according to LSD (P $<0.05)$.

A: 'Yliangyou-689' in 2018; B: 'Zheyou-18' in 2018; C: 'Yliangyou-689' in 2019; D: 'Zheyou-18' in 2019.

\section{DISCUSSION}

Submergence occurring at the vegetative growth stage of rice will cause negative effects on inbred rice, reducing the survival of individuals and grain yield. The degree of harm to submerged rice depends on such factors as the depth and duration of submergence and the turbidity of the water (Das et al., 2009). In our study, we flooded the hybrid rice cultivars with clear tap water to a depth of $43 \mathrm{~cm}$ for about $2 \mathrm{wk}$ at the vegetative growth stage and found the submergence stress also lowered the survival rate of submerged plants compared to that of the control plants of both cultivars, which was the same result as that of the inbred rice. However, the difference between control and submergence was only significant in the indica hybrid rice 'Yliangyou-689' in 2019 (Table 1), and the negative impact of the submergence to the survival of indica-japonica hybrid rice is relatively limited.

Numerous studies indicate that indica-japonica hybrid rice has high yield potential and thus has been used widely in China's rice production systems (Bian et al., 2020; Wei et al., 2020). In our experiment, however, we found the indica-japonica hybrid rice, 'Zheyou-18', produced a lower grain yield than the grain yield of the indica hybrid rice, 'Yliangyou-689', in both the control and submergence treatments (Table 2). The reason for this phenomenon was unclear, perhaps is the amount of fertilizers we applied, especially the $\mathrm{N}$ inputs was insufficient for 'Zheyou-18' to achieve higher yields because indica-japonica hybrid rice is known to have high $\mathrm{N}$ requirements (Meng et al., 2018). However, we found that grain yield of 'Yliangyou-689' was more strongly and significantly reduced by nearly $50 \%$ due to the submergence treatment, while that of 'Zheyou-18' was less affected. In fact, the reduction of yield in 'Zheyou-18' due to submergence was nonsignificant. These results suggest that the indica-japonica hybrid rice may have a higher tolerance to submergence at the vegetative growth stage than the indica hybrid rice may have. 
Figure 3. Shoot elongation rates (SER) of two rice cultivars for two sampling periods: during the submergence and from $1 \mathrm{~d}$ after de-submergence to the maturity stage of rice. Non-submerged (control) plants were sampled at the same time as submerged plants.
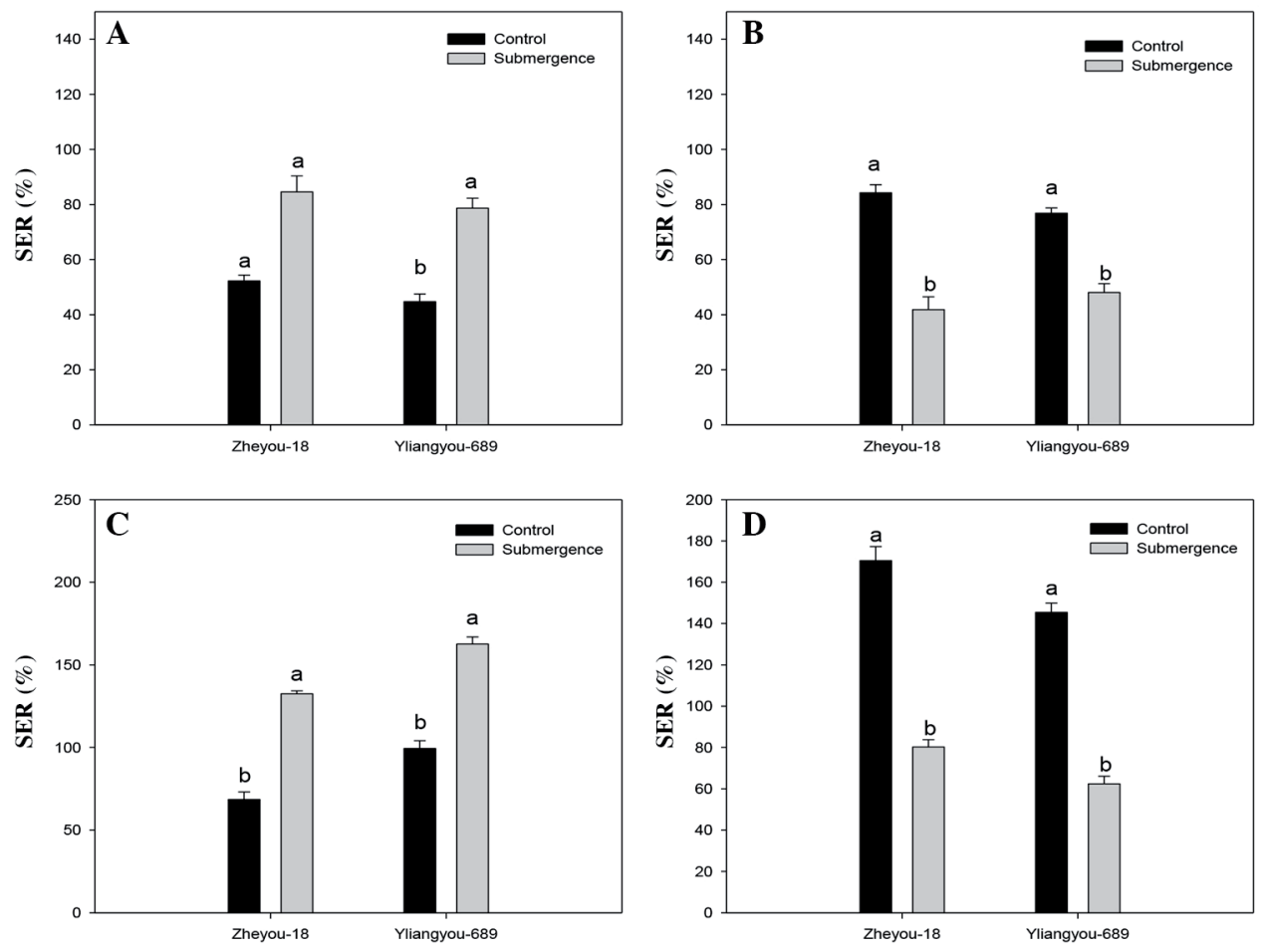

Vertical bars represent the SE of the means $(n=3)$.

Within each sampling period in each year of study, bars marked by different letters indicate significant differences according to LSD (P <0.05). A: Shoot elongation during submergence in 2018; B: Shoot elongation from $1 \mathrm{~d}$ after de-submergence to maturity in 2018; C: Shoot elongation during submergence in 2019; D: Shoot elongation from $1 \mathrm{~d}$ after de-submergence to maturity of individuals in 2019.

Table 4. Contents and uptake rates of $\mathrm{N}$ and $\mathrm{K}$ of two rice cultivars subjected to no submergence (control) or submergence treatments and sampled in 2018 and 2019.

\begin{tabular}{|c|c|c|c|c|c|c|c|}
\hline Year & Cultivar & Treatment & Sampling time & $\mathrm{NC}$ & $\mathrm{KC}$ & $\mathrm{NU}$ & $\mathrm{KU}$ \\
\hline & & & & 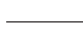 & - & 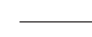 & - \\
\hline \multirow[t]{8}{*}{2018} & Yliangyou-689 & Control & BS & $21.6 \mathrm{a}$ & $42.4 \mathrm{a}$ & $7.63 \mathrm{a}$ & $14.92 \mathrm{a}$ \\
\hline & & Submergence & BS & $24.9 \mathrm{a}$ & $40.8 \mathrm{a}$ & $3.86 \mathrm{~b}$ & $6.28 b$ \\
\hline & Zheyou-18 & Control & BS & $25.8 \mathrm{a}$ & $40.8 \mathrm{a}$ & $8.14 \mathrm{a}$ & $12.81 \mathrm{a}$ \\
\hline & & Submergence & BS & $27.4 \mathrm{a}$ & $40.8 \mathrm{a}$ & $1.82 \mathrm{~b}$ & $2.75 b$ \\
\hline & Yliangyou-689 & Control & AS & $33.1 \mathrm{a}$ & $42.3 \mathrm{a}$ & $13.98 \mathrm{a}$ & $17.99 \mathrm{a}$ \\
\hline & & Submergence & AS & $33.4 \mathrm{a}$ & $39.8 \mathrm{a}$ & $5.09 \mathrm{~b}$ & $6.08 b$ \\
\hline & Zheyou-18 & Control & AS & $37.6 \mathrm{a}$ & $44.4 \mathrm{a}$ & $19.80 \mathrm{a}$ & $23.28 \mathrm{a}$ \\
\hline & & Submergence & AS & $38.0 \mathrm{a}$ & $41.0 \mathrm{a}$ & $2.23 \mathrm{~b}$ & $2.43 b$ \\
\hline \multirow[t]{14}{*}{2019} & Yliangyou-689 & Control & BS & $37.9 \mathrm{a}$ & $37.2 \mathrm{a}$ & $0.68 b$ & $0.67 \mathrm{~b}$ \\
\hline & & Submergence & BS & $37.5 \mathrm{a}$ & $35.6 \mathrm{a}$ & $1.06 \mathrm{a}$ & $1.01 \mathrm{a}$ \\
\hline & Zheyou-18 & Control & BS & $37.1 \mathrm{a}$ & $39.9 \mathrm{a}$ & $0.71 \mathrm{a}$ & $0.77 \mathrm{a}$ \\
\hline & & Submergence & BS & $38.9 \mathrm{a}$ & $36.5 \mathrm{a}$ & $0.83 \mathrm{a}$ & $0.78 \mathrm{a}$ \\
\hline & Yliangyou-689 & Control & AS & $30.6 \mathrm{a}$ & $43.4 \mathrm{a}$ & $4.91 \mathrm{a}$ & $7.55 \mathrm{a}$ \\
\hline & & Submergence & AS & $26.0 \mathrm{a}$ & $39.9 \mathrm{a}$ & $2.26 \mathrm{~b}$ & $3.48 \mathrm{~b}$ \\
\hline & Zheyou-18 & Control & AS & $28.3 \mathrm{a}$ & $39.9 \mathrm{a}$ & $3.16 \mathrm{a}$ & $5.11 \mathrm{a}$ \\
\hline & & Submergence & AS & $25.3 \mathrm{a}$ & $40.6 \mathrm{a}$ & $1.51 \mathrm{a}$ & $2.14 b$ \\
\hline & & ANOVA results & & & & & \\
\hline & & Year (Y) & & NS & $* *$ & $* *$ & $* *$ \\
\hline & & Treatment $(\mathrm{T})$ & & NS & NS & $* *$ & $* *$ \\
\hline & & Cultivar (C) & & NS & NS & NS & NS \\
\hline & & $\mathrm{Y} \times \mathrm{T}$ & & NS & NS & $* *$ & $* *$ \\
\hline & & $\mathrm{C} \times \mathrm{T}$ & & NS & NS & NS & NS \\
\hline
\end{tabular}

Within columns for each treatment, means followed by different letters are significantly different according to LSD $(\mathrm{P}<0.05)$.

NC: N content; KC: K content; NU: N uptake rate; KU: K uptake rate; BS: $1 \mathrm{~d}$ before submergence; AS: $1 \mathrm{~d}$ after de-submergence.

*, $*$ Significant differences at the 0.05 and 0.01 probability levels, respectively. NS: Nonsignificant. 
Table 5. Rapid visco analyzer values of two rice cultivars subjected to no submergence (control) or submergence treatments.

\begin{tabular}{|c|c|c|c|c|c|c|c|c|c|}
\hline Year & Cultivars & Treatment & PV & TV & $\mathrm{FV}$ & $\mathrm{BD}$ & SB & PT & Pat \\
\hline & & & & & $\mathrm{mPa} \mathrm{s}^{-1}$ & & & $\min$ & ${ }^{\circ} \mathrm{C}$ \\
\hline \multirow[t]{4}{*}{2018} & Yliangyou-689 & Control & $1357.0 \mathrm{~b}$ & $1101.3 \mathrm{a}$ & $2080.3 \mathrm{a}$ & $256.3 \mathrm{a}$ & $979.0 \mathrm{a}$ & $5.7 \mathrm{a}$ & $88.0 \mathrm{a}$ \\
\hline & & Submergence & $1538.0 \mathrm{a}$ & $1197.3 \mathrm{a}$ & $2284.0 \mathrm{a}$ & $340.7 \mathrm{a}$ & $1086.7 \mathrm{a}$ & $5.7 \mathrm{a}$ & $88.0 \mathrm{a}$ \\
\hline & Zheyou-18 & Control & $1637.7 \mathrm{a}$ & $1356.7 \mathrm{a}$ & $2535.3 \mathrm{a}$ & $321.0 \mathrm{a}$ & $1218.7 \mathrm{a}$ & $5.8 \mathrm{a}$ & $88.8 \mathrm{a}$ \\
\hline & & Submergence & $1666.7 \mathrm{a}$ & $1316.7 \mathrm{a}$ & $2550.7 \mathrm{a}$ & $310.0 \mathrm{a}$ & $1194.0 \mathrm{a}$ & $5.8 \mathrm{a}$ & $87.5 \mathrm{a}$ \\
\hline \multirow[t]{9}{*}{2019} & Yliangyou-689 & Control & $1260.7 \mathrm{a}$ & $899.3 a$ & $1626.0 \mathrm{a}$ & $361.3 \mathrm{a}$ & $726.7 \mathrm{a}$ & $5.6 \mathrm{a}$ & $86.2 \mathrm{a}$ \\
\hline & & Submergence & $1178.7 \mathrm{a}$ & $879.7 \mathrm{a}$ & $1623.3 \mathrm{a}$ & $299.0 a$ & $744.7 \mathrm{a}$ & $5.6 \mathrm{a}$ & $88.2 \mathrm{a}$ \\
\hline & Zheyou-18 & Control & $1333.3 \mathrm{a}$ & $891.7 \mathrm{a}$ & $1656.0 \mathrm{a}$ & $236.7 \mathrm{a}$ & $764.3 \mathrm{a}$ & $5.7 \mathrm{a}$ & $89.1 \mathrm{a}$ \\
\hline & & $\begin{array}{l}\text { Submergence } \\
\text { ANOVA results }\end{array}$ & $1128.3 \mathrm{a}$ & $1052.3 \mathrm{a}$ & $1954.7 \mathrm{a}$ & $281.0 \mathrm{a}$ & $902.3 \mathrm{a}$ & $5.7 \mathrm{a}$ & $88.1 \mathrm{a}$ \\
\hline & & Year (Y) & $* *$ & $* *$ & $* *$ & NS & $* *$ & NS & NS \\
\hline & & Treatment $(\mathrm{T})$ & NS & NS & NS & NS & NS & NS & NS \\
\hline & & Cultivar (C) & NS & NS & NS & NS & NS & NS & NS \\
\hline & & $\mathrm{Y} \times \mathrm{T}$ & NS & NS & NS & NS & NS & NS & NS \\
\hline & & $\mathrm{C} \times \mathrm{T}$ & NS & NS & NS & NS & NS & NS & NS \\
\hline
\end{tabular}

Within columns for each treatment, means followed by different letters are significantly different according to LSD $(\mathrm{P}<0.05)$.

PV: Peak viscosity; TV: trough viscosity; FV: final viscosity; BD: breakdown; SB: setback; PT: peak time; Pat: pasting temperature.

$*$,**Significantly at the 0.05 and 0.01 probability levels, respectively. NS: Nonsignificant.

Rice grain yield is significantly positively correlated with number of spikelets per unit area (Banayo et al., 2018). Thus, our observations of significantly lower numbers of spikelets $\mathrm{m}^{-2}$ in the submergence treatments than in controls of the two hybrid cultivars (Table 2) likely explains the reduced grain yields produced from the submerged rice. The number of spikelets $\mathrm{m}^{-2}$ was likely determined by the numbers of panicles $\mathrm{m}^{-2}$ and spikelets per panicle (Yao et al., 2016). The number of panicles is affected by the number of tillers at the tillering stage (Ao et al., 2010). Previous studies indicate that tiller number will decline sharply during submergence (Kato et al., 2014; Zhu et al., 2019), and in our study, we also found that tiller number decreased greatly in the submergence treatment than compared to that in the control. Accordingly, the lower tiller numbers led to reduced panicle number at the maturity stage (Figure 1).

Inbred rice cultivars are submergence intertolerant because when subjected to submergence, the stem is induced to excessively elongate, resulting in depletion of carbohydrate reserves (Ella et al., 2003), and greater susceptibility of these taller shoots to lodging (Xiang et al., 2017). Similar to the response of inbred cultivars to submergence, we observed faster rates of increase in shoot lengths of both hybrid rice cultivars (Figures 3A, 3C). However, plant height at the maturity stage was higher in the control treatment than in the submergence treatment, and shoot lengths in the period between desubmergence and maturity was also higher in the control treatment than that in the submergence treatment. These results indicate that submergence began to limit shoot growth in height from the first day after de-submergence to when plants reached maturity (Figures 3B, 3D).

Numerous studies have indicated that leaf photosynthetic rates of submerged inbred rice will be reduced because light intensity and gas diffusion rates rapidly decline under water (Gautam et al., 2015; Zhu et al., 2019). Consequently, contents of non-structural carbohydrates (NSC) in rice stems and biomass accumulation are reduced. Congruent with these studies, we found that submergence occurring at the vegetative growth stage decreased dry weight measured $1 \mathrm{~d}$ after de-submergence and decreased crop growth rate (CGR) measured during the submergence of both hybrid rice cultivars (Table 3), which will also bring negative effects to the grain yield of hybrid rice. The above results altogether suggest that the primary causal reasons of the yield loss the indica hybrid rice 'Yliangyou-689' under the submergence treatment was the reduced survival rate, numbers of tillers and spikelets, plant dry weight, and crop growth rate and the excessive shoot elongation during submergence.

Nitrogen and $\mathrm{K}$ are two of the most important nutrients for rice and both can become unavailable for plant uptake if lost by soil erosion (Yan et al., 2011; Chowaniak and Niemiec, 2020). In our results, we found that $\mathrm{N}$ and $\mathrm{K}$ contents in rice were non significantly different between the control and submergence treatment in the two hybrid cultivars (Table 4), which indicated that the submergence stress will not exacerbate $\mathrm{N}$ and $\mathrm{K}$ losses in hybrid rice plants. However, rice growth was inhibited during the submergence and $\mathrm{N}$ and $\mathrm{K}$ uptake rates after de-submergence were reduced significantly under the 
submergence treatment than under the control, indicating the ability of hybrid rice to absorb these nutrients was limited during the submergence. Though we suspect that it is possible to enhance the rice recovery rate after flooding has receded by applying sufficient topdressing of $\mathrm{N}$ and $\mathrm{K}$ fertilizer after de-submergence.

Studies that focus on the effects of submergence at the vegetative growth stage on hybrid rice quality have been limited. Hence, we obtained the rice rapid visco analyzer (RVA) data to reflect rice cooking and eating qualities of the hybrid cultivars. Rice with high cooking and tasting qualities usually have high breakdown values and low setback values (Tang et al., 2019). The RVA data of our two hybrid rice cultivars (Table 5) showed that there were nonsignificant differences between the control and submergence treatments in all of the RVA parameters except the peak viscosity value of 'Yliangyou-689' in 2018, indicating that submergence will likely have few negative effects on the rice cooking and tasting qualities of hybrid rice.

\section{CONCLUSIONS}

Generally speaking, the results of our research indicated that the submergence occurred at the rice vegetative growth stage with $43 \mathrm{~cm}$ deep tap water for about 2 wk did not significantly decrease survival rate and grain yield in the indicajaponica hybrid rice, 'Zheyou-18', as it did in the indica hybrid rice, 'Yliangyou-689', by about $50 \%$ of the grain yield of its respective control. Thus, the indica-japonica hybrid rice likely has a higher submergence tolerance than the indica hybrid rice. Overall, the reductions in yield due to submergence is likely due to the reduced numbers of spikelets and tillers, lower plant dry weight and crop growth rate, and greater elongation rate of stems. The submergence did not enhance the $\mathrm{N}$ and $\mathrm{K}$ losses in hybrid rice plants, but inhibited the $\mathrm{N}$ and $\mathrm{K}$ uptake significantly, and topdressing the $\mathrm{N}$ and $\mathrm{K}$ fertilizer after de-submergence perhaps is necessary for the hybrid rice recovery. The results also indicate that the occurrence of submergence at the vegetative growth stage will not affect the parameters measured by the rapid visco analyzer from the two hybrid rice cultivars. The results presented in our study provide empirical data that can be used to inform cultivation and breeding methods to improve hybrid rice submergence tolerance in the future.

\section{ACKNOWLEDGEMENTS}

We thank the funding provided by the National Natural Science Foundation of China (31701364), and the National Key Research and Development Program of China (2016YFD0200800).

\section{REFERENCES}

Ao, H., Peng, S., Zou, Y., Tang, Q., and Visperas, R.M. 2010. Reduction of unproductive tillers did not increase the grain yield of irrigated rice. Field Crops Research 116:108-115.

Bailey-Serres, J., Fukao, T., Gibbs, D.J., Holdsworth, M.J., Lee, S.C., Licausi, F., et al. 2012. Making sense of low oxygen sensing. Trends in Plant Science 17(3):129-138.

Banayo, N.P.M.C., Bueno, C.S., Haefele, S.M., Desamero, N.V., and Kato, Y. 2018. Site-specific nutrient management enhances sink size, a major yield constraint in rainfed lowland rice. Field Crops Research 224:76-79.

Banerjee, A., and Roychoudhury, A. 2020. Physiological and genetic basis of submergence tolerance in rice. p. 399-406. In Roychoudhury, A. (ed.) Rice research for quality improvement: Genomics and genetic engineering. Volume 1: Breeding techniques and abiotic stress tolerance. Springer, Singapore.

Bian, J., Ren, G., Han, C., Xu, F., Qiu, S., Tang, J., et al. 2020. Comparative analysis on grain quality and yield of different panicle weight indica-japonica hybrid rice (Oryza sativa L.) varieties. Journal of Integrative Agriculture 19(4):999-1009.

Chen, L., Xiao, Y., Tang, W., and Lei, D. 2007. Practices and prospects of super hybrid rice breeding. Rice Science 14(2):71-77.

Chen, Y., Yan, Q., and Xiao, G. 2005. Progress in research of submergence tolerance in rice. Chinese Agricultural Science Bulletin 21(12):151-153 (In Chinese with English abstract).

Chowaniak, N., and Niemiec, M. 2020. Effect of a tillage system and plant cover on phosphorus and potassium losses due to surface runoff. Journal of Elementology 25(3):917-929.

Collard, B.C.Y., Septiningsih, E.M., Das, S.R., Carandang, J.J., Pamplona, A.M., Sanchez, D.L., et al. 2013. Developing new flood-tolerant varieties at the International Rice Research Institute (IRRI) towards 2025. Sabrao Journal of Breeding and Genetics 45:42-56. 
Das, K.K., Panda, D., Sarkar, R.K., Reddy, J.N., and Ismail, A.M. 2009. Submergence tolerance in relation to variable floodwater conditions in rice. Environmental and Experimental Botany 66:425-434.

Deng, X., Wang, H., Tang, X., Zhou, J., Chen, H., He, G., et al. 2013. Hybrid rice breeding becomes a new era of molecular crop design. Scientia Sinica Vitae 43:864-868 (In Chinese with English abstract).

Ella, E.S., Dionisio-Sese, M.L., and Ismail, A.M. 2011. Application of silica before sowing negatively affects growth and survival of rice following submergence. Philippine Journal of Crop Science 36(2):1-11.

Ella, E.S., and Ismail, A.M. 2006. Seedling nutrient status before submergence affects survival after submergence in rice. Crop Science 46:1673-1681.

Ella, E.S., Kawano, N., Yamauchi, Y., Tanaka, K., and Ismail, A.M. 2003. Blocking ethylene perception enhances flooding tolerance in rice seedlings. Functional Plant Biology 30:813-819.

Gautam, P., Lal, B., Raja, R., Tripathi, R., Shahid, M., Baig, M.J., et al. 2015. Effect of simulated flash flooding on rice and its recovery after flooding with nutrient management strategies. Ecological Engineering 77:250-256.

Gautam, P., Nayak, A.K., Lal, B., Bhattacharyya, P., Tripathi, R., Shahid, M.D., et al. 2014. Submergence tolerance in relation to application time of nitrogen and phosphorus in rice (Oryza sativa L.) Environment and Experimental Botany 99:159-166.

Hao, Y. 2012. The utilization of tolerance rice germplasm and the influence of submergence on carbohydrate accumulation and transformation. Master's Thesis. College of Plant Science \& Technology, Huazhong Agricultural University, Wuhan, China (In Chinese with English Abstract).

Huang, S., Jia, Y., Liu, P., Dong, H., and Tang, X. 2020. Effect of ultrasonic seed treatment on rice seedlings under waterlogging stress. Chilean Journal of Agricultural Research 80:561-571.

Huang, S., Wang, L., Liu, L., Fu, Q., and Zhu, D. 2014. Nonchemical pest control in China rice: a review. Agronomy for Sustainable Development 34:275-291.

Ismail, A.M., Singh, U.S., Singh, S., Dar, M.H., and Mackill, D.J. 2013. The contribution of submergence-tolerant (sub1) rice varieties to food security in flood-prone rainfed lowland areas in Asia. Field Crops Research 152:83-93.

Kato, Y., Collard, B.C.Y., Septiningsih, E.M., and Ismail, A.M. 2014. Physiological analyses of traits associated with tolerance of long-term partial submergence in rice. AoB Plants 6:plu058.

Kawano, N., Ella, E.S., Ito, O., Yamauchi, Y., and Tanaka, K. 2002. Comparison of adaptability to flash flood between rice cultivars differing in flash flood tolerance. Soil Science and Plant Nutrition 48(5):659-665.

Li, L., Ni, J., Chen, Q., and Li, X. 2013. Development and prospect of hybrid rice seed industry in China. Seed 32(2):56-60 (In Chinese).

Liu, Z., Zhang, W., Zhang, Y., Chen, T., Shao, S., Li. Z., et al. 2019. Assuring food safety and traceability of polished rice from different production regions in China and Southeast Asia using chemometric models. Food Control 99:1-10.

Meng, T., Wei, H., Li, X., Dai, Q., and Huo, Z. 2018. A better root morpho-physiology after heading contributing to yield superiority of japonicalindica hybrid rice. Field Crops Research 228:135-146.

Peng, S. 2016. Dilemma and way-out of hybrid rice during the transition period in China. Acta Agronomica Sinica 42(3):313-319 (In Chinese with English Abstract).

Septiningsih, E.M., Pamplona, A.M., Sanchez, D.L., Neeraja, C.N., Vergara, G.V., Heuer, S., et al. 2009. Development of submergence tolerant rice cultivars: the Subl locus and beyond. Annals of Botany 103:151-160.

Tang, S., Zhang, H., Liu, W., Dou, Z., Zhou, Q., Chen, W., et al. 2019. Nitrogen fertilizer at heading stage effectively compensates for the deterioration of rice quality by affecting the starch-related properties under elevated temperatures. Food Chemistry 277:455-462.

Wang, H., and Deng, X. 2018. Development of the "Third-Generation" hybrid rice in China. Genomics, Proteomics \& Bioinformatics 16(6):393-396.

Wei, H., Yang, Y., Shao, X., Shi, T., Meng, T., Lu, Y., et al. 2020. Higher leaf area through leaf width and lower leaf angle were the primary morphological traits for yield advantage of japonicalindica hybrids. Journal of Integrative Agriculture 19(2):483-494.

Xiang, J., Wu, H., Zhang, Y., Zhang, Y., Wang, Y., Li, Z., et al. 2017. Transcriptomic analysis of gibberellin- and paclobutrazoltreated rice seedlings under submergence. International Journal of Molecular Science 18(10):2225.

Yan, X., Cai, Z., Yang, R., Ti, C., Xia, Y., Li, F., et al. 2011. Nitrogen budget and riverine line nitrogen output in a rice paddy dominated agricultural watershed in eastern China. Biogeochemistry 106:489-501.

Yao, F., Huang, J., Nie, L., Cui, K., Peng, S., and Wang, F. 2016. Dry matter and N contributions to the formation of sink size in early and late-maturing rice under various N rates in central China. International Journal of Agricultural \& Biology 18:46-51.

Zhu, G., Chen, Y., Ella, E.S., and Ismail, A.M. 2019. Mechanisms associated with tiller suppression under stagnant flooding in rice. Journal of Agronomy and Crop Science 205(2):235-247. 